\title{
Adaptation of the Novel The Stranger: A Comparative Framing Analysis of the Films Lo Straniero and Yazgl
}

\section{Yabancı Romanının Sinemaya Uyarlanmast: Lo Straniero ve Yazgı Filmlerinin Karşılaştırmalı Çerçeveleme Analizi}

\author{
Zuhal AKMEŞE ${ }^{1 \odot}$
}

${ }^{1} \mathrm{PhD}$. Res. Asst., Dicle University, Faculty of Communication, Diyarbakır, Turkey

ORCID: 0000-0003-3805-8649

Sorumlu yazar/Corresponding author:

Zuhal Akmeşe,

Dicle Üniversitesi, İletişim Fakültesi, Radyo TV ve Sinema Bölümü, Diyarbakır, Türkiye E-posta/E-mail: zuhalakmese@gmail.com

Geliş tarihi/Received: 07.10.2019 Revizyon talebi/Revision Requested: 05.11.2019

Son revizyon teslimi/Last revision received: 23.11 .2019

Kabul tarihi/Accepted: 06.12.2019

Atıf/Citation: Akmese, Z. (2019). Adaptation of the novel The Stranger: a comparative framing analysis of the films Lo Straniero and Yazgı. Connectist: Istanbul University Journal of Communication Sciences, 57, 1-23.

https://doi.org/10.26650/CONNECTIST2019-0064

\begin{abstract}
As in all works of art, cinema derives its origin from life and also reproduces life's subjects per its own understanding. Cinema is in interaction with all the branches of art that existed before it. Among these branches of art, literature is the one it interacts with the most. This strong relationship between literature and cinema stems from their ability to explain the topics they deal with in detail. Since both fields of art are nourished by similar dynamics, many works have been adapted from literature to cinema. The first adaptation from literature to cinema in history is Melies's movie A Trip to the Moon (1902), which was inspired by Jules Verne and H. G. Wells's books; this film is followed by many more adaptations, the film A Trip to the Moon has an important place in the history of cinema as it is both the first adaptation and the first example of the science fiction genre. Today, the technique of adapting from literature to cinema is among the methods used by many directors. This study focuses on the films Lo Straniero (1967) and Yazgı (2001), which were adapted for the cinema from Albert Camus's novel The Stranger (L'Étranger, 1942) by two different directors (Luchino Visconti and Zeki Demirkubuz) in different years. The reason The Stranger was chosen for this study is that is effective all over the world, there are traces of existentialism, and it conveys the depression and alienation experienced by the people of the period. For this reason, these two adaptation films were selected for the study. After analyzing Albert Camus's literary understanding and The Stranger novel, the general story of these two films and the main characters (Meursault in Lo Straniero, Musa in Yazgı) were analyzed by comparative framing analysis. After the analyses it was discovered that, while Luchino Visconti's movie was a direct adaptation of the novel, Zeki Demirkubuz made free adaptation inspired by the novel.
\end{abstract}

Keywords: Cinema, film adaptation, framing analysis, absurd, The Stranger 
ÖZ

Bütün sanat yapıtlarında olduğu gibi sinema da kaynağını yaşamdan alır ve yaşamdan aldığı konuları kendi anlayışına uygun bir biçimde yeniden üretir. Sinema, kendisinden önce var olan bütün sanat dallarıyla bir etkileşim içerisinde olmuştur. Bu sanat dalları içerisinde en çok etkileşime girdiği alan ise edebiyattır. Edebiyat ve sinema arasındaki bu güçlï ilişki, roman ve filmlerin ele aldıkları konuları detaylı bir şekilde anlatabilme özelliğinden ileri gelmektedir. İki sanat alanı da benzer dinamiklerden beslendiği için bir çok eser edebiyattan sinemaya uyarlanmıştır. Tarihte edebiyattan sinemaya ilk uyarlama Jules Verne ve H. G. Wells'in kitaplarından esinlenen Melies'in 1902 yılında çektiği Trip to the Moon (Aya Yolculuk) filmidir. Bu filmi birçok uyarlama izler (Aya Yolculuk filmi hem ilk uyarlama hem de bilimkurgu türünün ilk örneği olması dolayısıyla sinema tarihinde önemli bir yer tutmaktadır). Günümüzde de edebiyattan sinemaya uyarlama tekniği birçok yönetmen tarafından başvurulan yöntemler arasında yer almaktadır. Çalışma, farklı tarihlerde Albert Camus'nün Yabancı (L'Étranger, 1942) romanından iki farklı yönetmen (Luchino Visconti ve Zeki Demirkubuz) tarafından sinemaya uyarlanan Lo Straniero (1967) ve Yazgı (2001) filmlerini odağına almaktadır. Albert Camus'nün edebiyat anlayışı ve Yabancı romanı ele alındıktan sonra örneklemi oluşturan iki filmin genel öyküsü ve ana karakterleri (Lo Straniero filminde Mearsult, Yazgı filminde Musa) karşılaştırmalı çerçeveleme çözümlemesi yöntemiyle incelenmiş, Luchino Visconti'nin romanı sinemaya birebir uyarladığı, Zeki Demirkubuz'un ise romandan esinlenerek serbest uyarlama yaptığı tespit edilmiştir.

Anahtar Kelimeler: Sinema, uyarlama, çerçeveleme çözümlemesi, saçma, Yabancı

\section{INTRODUCTION}

"No man can say what he is. But sometimes he can say what he is not."

Albert Camus

Cinema has been in interaction with all branches of art from the very beginning. Throughout the development period, it has exchanged information in terms of subject, technique, and method and benefited from all branches of art. The main reason why cinema benefits from all branches of art is that all fields of art take their subject from life and cinema reflects life. Among the branches of art, it is literature that has been a particularly rich source for cinema in terms of both technique and content. When we look at the history of cinema, it can be that many works of art, especially in the field of literature, have been adapted for the cinema both in world cinema and in Turkish cinema. This strong relationship between cinema and literature stems from the fact that novels and cinema have similar characteristics. Taking their subjects from life, telling about people and their experiences, having a certain dramatic structure of the narrative and relying on fiction enables these two forms of art to feed from each other. Tarkovsky attributes the similarities of these two distinctive and independent branches of art to the unique freedom that the creator has in reshaping the material he/she takes from life (Tarkovsky, 2018). Apart from the similarity of the methods and narrative forms, factors such as commercial anxiety (Çetin Erus, 2005, p. 12), the need of cinema to tell 
stories, the problem of finding new subjects, and seeing literary works as ready-made source material are also effective (Kırel, 2004, p. 118). One reason for preferring literary works that have reached a certain audience is that the audience of the adapted work is seen as a potential audience for the film. Çetin Erus (2000, p. 48) stated that cinema and novel are not only mass media but also storytelling tools, and that the story which is the common ground for both forms of art, is the most important element of novel and film which can be transferred from one to the other.

The word adaptation in the lexicon of the Turkish Language Institution is defined as follows: "Adaptation work, adaptation, pre. adapting a work to the lifestyle and beliefs of the people it's adapted for, tech. Fitting, adj. Adapted" ("Uyarlama...," 2019). When the concept is considered in the context of novel and cinema, is it described as: "handling a novel in accordance with the characteristics of the art of cinema and put into a script format" (Çetin Erus, 2005, p. 16), "putting a text that is not prepared for cinema into a format suitable for cinema" (Özön, 2000, p. 732). Adaptations from literature to cinema take place in three ways. These are: real or direct transfer (transportation), interpretation or some changes made by the adaptation (commentary), and inspired or free adaptation (analogy) (Kırel, 2004, p. 119; Çetin, 1999, p. 152; Scognamillo, 1973, p. 69). As can be understood from the definitions, while direct transfer is to convert the work into cinema form without interfering with the original, in commentaries the work is interpreted on the condition that it maintains its general characteristics, and free adaptation allows the director and screenwriter to freely form the work.

The study of film adaptations, particularly those coming from literature, has been growing at a rapid rate during the last years due to the amount of adaptations coming from both mainstream and independent film industries (Vergara, 2015, p. 154). In this study, The Stranger and its film adaptations are analyzed in the context of film adaptations by framing theory. It is useful to underline why The Stranger has been selected as a study item: The Stranger, published by Albert Camus in 1942 and considered to be his most important work in literature, focuses on the character Meursault and narrates the philosophy of absurdism from a nihilism-based existential perspective (Biricik, 2016, pp. 86-92). The Stranger, which is considered to be Camus's most prominent work, is also one of the most recognized, translated, and studied books, and is still a best-seller. It was highly acclaimed by many critics, awarded the Nobel Prize in Literature in 1957, and was named one of Le Monde's 100 Books of the Century ("The Stranger...," 2019). This study aims to describe in the context of framing analysis of two different adaptations 
of the book The Stranger directed by two different directors (Luchino Visconti - Zeki Demirkubuz) in different years.

The Stranger is effective all over the world, there are traces of existentialism, it conveys the depression and alienation experienced by the people of the period. In addition, it is a work that reflects the relationship between adaptation and cinema by two different directors who have made a name for themselves in the cinema of their countries and also in the world. In line with this aim, Albert Camus's philosophical thought and The Stranger novel were first discussed and in this context, the filmmakers' understanding of cinema in the axis of absurdity concept of existentialist philosophy was examined. There are studies about The Stranger of Albert Camus in the fields of philosophy and literature both in Turkey and in the world, yet, the number of intertextuality studies is very limited. There are some studies that focus on Albert Camus'The Stranger and the Meursault: Özyön's article titles "Camus's Meursault: From an Existentialist Angle”, Islam and Islam's article titled "Albert Camus' Meursault in the Outsider: An Existential Hero and Beyond"; Shobeiri's article titled "Meursault, an Absurd Happy Man"; Ashkan Shobeiri and Wan Roselezam Wan Yahya's article titled "Truth and Honesty in Albert Camus's Absurd Hero, Meursault"; Aidan Curzon-Hobson, "Confronting the Absurd: An educational reading of Camus'The Stranger". When the studies are examined, it is seen that the work is evaluated in the context of existential philosophy, and the alienation, death, indifference, and similar issues are examined with the absurdism in the center. When the studies handling Visconti and Demirkubuz's films and The Stranger novel together were examined, no study was found on the comparison of these works except for Mikail Boz's work titled "Adaptation in Cinema: A Comparison Between Albert Camus' L'Étranger and Zeki Demirkubuz's Yazgı."

In this context, after focusing on the relationship between cinema and literature, this study discusses the novelist Albert Camus and his philosophical views in the context of The Stranger novel before moving on to the framing analysis of the novel and the two films adapted from the novel. Subsequently, how the two main characters, Meursault in Lo Straniero and Musa in Yazgı are framed in the Italian director's one-to-one-adaptation of Lo Straniero and the Turkish director's free adaptation of Yazgı (or in his own words 'conveyed to the cinema through inspiration') is analyzed in the context of the signs and discourses in the films, using comparative framework analysis. An evaluation is made on the process of creation of film by adapting works from literature to cinema, within the frames established by the director, and production of meaning. 
For this study, new realism is one of the important notion; New Realism, rather than being a school or an art movement, was a part of a new way of representing wartime Italy and the reality of the Resistance in the cinema of the time (Sivas, 2010, p. 43). The fact that the new realism movement contains a wide range of insights and that it consists of directors with different ideologies supports this interpretation. The new Realism movement is often initiated by Roberto Rossellini's Citta Aperta (1945) in various sources. However, when Visconti's Ossessione, which has New Realistic features, is taken into account, it is more suitable to start the movement from 1942 (Sivas, 2010, p. 45). As the main factor that strengthens this determination, it is possible to say that Ossessione initiated a new style against the cinema conception that existed in Italian cinema which corresponded to the New Realistic movement. The New Realism movement lost its popularity after nearly a decade in Italian cinema and is considered to end in 1952 with Vittorio De Sica's Umberto D. (1952). Rossellini and De Sica are considered to be the most important directors of this period together with Visconti (Sivas, 2010, pp. 45-47). In terms of cinematography, Visconti's understanding of cinema has changed in parallel with the changing conditions of Italy and the world and new technologies developed in the field of cinema and this change has been reflected in the films of the director. Visconti, during the period of the New Realism movement, made films acclaimed in the world of cinema. In addition to cinema, it is known that he wrote very effective works in the fields of theater and opera. Visconti staged about 60 theater, opera and ballet works from 1945 until his death (Geitel et al., 2006, p. 174). Visconti's 1960 film Rocco e I Suoi Fratelli (1960) was recognized as one of the masterpieces of the new Italian cinema and at the same time presented the latest cores of the New Realism movement. This situation is expressed by Ala Sivas as follows: Luchino Visconti, who moved away from the New Realism movement in the 50s, produced both one of the masterpieces of the new Italian cinema with Rocco e / Suoi Fratelli in 1960 and presented the New Realism movement to the cinema audience for the last time (2010, p. 114).

Due to its nature, cinema has been intertwined with all domains of art since its inception. Literature is the area of art most intertwined with the cinema. This relationship between literature and cinema relies on the characteristic trait of novels and films which allow both to explain in detail the themes which are introduced by them. The fact that the main theme of both forms of art pertain to life and that both are nurtured by similar dynamics and based on fiction, paves the way for several literary works to be adapted to films. The point of departure of this study relates to adaptations where the interaction between cinema and literature is persistently 
observed. Adaptation from literature to cinema can be briefly described as the reconfiguration of a literary work for a cinema film and the writing of a script based on a novel or a story, which was authored previously with no specific purpose of being adapted to film, by approaching the novel or story from the perspective of narrative cinema art (Bolat, 2019, pp. 512-513). Since the beginning of the art of cinema, quite a few classical and popular novels have been filmed. However, this does not necessarily imply that these cinema films reflect on a one-to-one basis the novels that they are adapted from. How the literary work to be adapted to the film is reconfigured and whether this literary work serves as the basis of direct adaptation or inspiration are matters of particular importance in view of the nature of the relationship established between the novel and the film (Boz, 2014, p. 113). At this juncture, a film director's approach to and viewpoint on the literary work to be adapted as well as frameworks established by the director while configuring the film, act as the primary determinants. In this respect, the study first focuses on a general perspective on The Stranger, the novel by Albert Camus, and Lo Straniero and YazgI (Fate), films adapted by two different film directors from 'The Stranger', and then, by analyzing all these works in detail, the study identifies the main characters of the novel 'The Stranger' and its two film adaptations through the comparative framing analysis method and explores how film directors framed the main characters and to what extent they adhered to the original plot line of the novel.

Framing analysis is a functional method allowing for a qualitative analysis of novels and films as well as offering the opportunity to explore them through a holistic perspective. Through these three works, the art understandings and the viewpoints of author and film directors, and the philosophical perspectives and art movements that they represent were analyzed and in light of this analysis, the main characters of these three works were deeply studied and compared. The frameworks established by film directors play a determining role in the development of a specific understanding of the event which is underlined in the story and in the conception of this event which, through visual imagery, embodies key words, metaphors, concepts and symbols emphasized in the narrative. These frameworks act as the reference points as to how the target audience should see the message and how the messages will be perceived by the target audience. In framing analysis, content to be analyzed is basically studied in terms of its three aspects, that is, 'thematic framing,"'contextual framing' and'picture framing' of the work. In picture framing, the frame, composition, camera and configuration facets are included in the analysis (Akmeşe, 2017). These three aspects of framing were 
taken into consideration in the comparative framing analysis of the two films. The theme of the film/novel was stressed through thematic framing, and story of the film/ novel was addressed through contextual framing. As for the picture framing, descriptions used by the author were enunciated for analyzing the novel, The Stranger, whereas the analyzing of the films depended on as to what types of picturing techniques were used for supporting the theme and story.

Upon a detailed analysis of the novel and films through different aspects of the framing analysis method and comparison of structural schemes of these three works, it was ascertained that thematic, contextual and picture framing aspects were adapted by Luchino Visconti from the novel, The Stranger, to Lo Straniero on a one-to-one basis and were supported with similar framings. On the other hand, it was found that Zeki Demirkubuz included the thematic aspect of the novel, The Stranger, to Yazgı only to a certain extent, that he addressed the film through an absolutely different approach in terms of the contextual framing aspect and that he used images adhering only to the frameworks established by himself in terms of picture framing aspect. That being the case, it is possible to suggest that Visconti adapted The Stranger to the film on a one-to-one basis whereas Demirkubuz was inspired by the novel only to a certain extent and, while configuring the film, created his own frameworks to serve as the reference. It is also possible to see these differences clearly through the comparison of main characters, Meursault and Musa, inasmuch as several elements included by Camus into the framework of the main character in the book were ruled out by Demirkubuz and new elements created by Demirkubuz himself were added to the framework of the main character.

Thus, it is a work that reflects the relationship between adaptation and cinema by two different directors who have made a name for themselves in the cinema of their countries and also in the world. Upon the detailed review of the novel and two films, it can be deduced that the frameworks established by Albert Camus in the novel, The Stranger, overlapped on a one-to-one basis with the film by Visconti, Lo Straniero, whereas the work by Zeki Demirkubuz, Yazgı, differed in terms of the contextual aspect although certain elements of the novel still existed in his film, and the director created a different work and main character by addressing the context through his own viewpoint. 


\section{AIM AND METHODOLOGY}

\section{Aim}

This study aims to examine how the main characters of the films Lo Straniero (1967) and Yazgı (2001), which were adapted to the cinema from Albert Camus's 1942 novel The Stranger, are framed by the directors and how closely they stick to the novel. The reason for this work is that The Stranger is effective all over the world, that there are traces of existentialism, and that it conveys the depression and alienation experienced by the people of the period. It is remarkable that the studies conducted both in the world and in Turkey are mainly in the field of literature and philosophy, and there has not been a deep and comprehensive study conducted in the field of communication and cinema, except for a limited number of studies in the context of adaptation. In this sense, it is important that this study handles these three works in the context of intertextuality within the context of adaptations from literature to cinema, in terms of evaluating the films of The Stranger novel adapted by two different directors together. The study is also the first in terms of comparing the three works in a holistic way by using the in-depth analysis opportunities offered by framing analysis. In this sense, it is thought that this study will provide a source and contribute to the literature both in terms of cinema literature and in the contexts of cinema-philosophy and cinema-literature.

The research is based on the comparative frame analysis of Meursault and Musa characters, the main characters of the films Lo Straniero and Yazgı, which were transferred to the cinema by the Italian director Luchino Visconti with the direct adaptation technique and the Turkish director Zeki Demirkubuz with the free adaptation technique. The frameworks established by the directors embody the keywords, metaphors, concepts, and symbols highlighted in the narrative with visual images, and are decisive in developing a certain understanding of the event in the story and perceiving the event.

Within the scope of the study, answers to these questions were sought:

- How is the subject of the novel adapted to the cinema?

- Is the story of the novel fully reflected in the films?

- Which frames were used by the directors to create their characters?

- What are the similar and different characteristics of the characters?

- Do the structural schemes in the novel and the films overlap? 


\section{Methodology}

Film criticism, which constitutes one of the most important areas of cinema studies, is considered as a creative discipline beyond giving information about the film (Kabadayı, 2013 , p. 2). Film analysis makes it possible to evaluate the cinematic product in the sociological, psychological, philosophical, ideological and historical context with interdisciplinary connections. In this context, Lo Straniero and Yazgı films, which are the adaptations of a literary work which is the subject of the study, are evaluated with framing analysis method in general context. This study analyses the two films with the analysis of the screenings of the main characters Meursault and Musa. In this study, the framing analysis method which enables qualitative analysis is used. Framing analysis is a method that allows the use of different methods together for the purpose of analysis of the media content (film, news, advertisement, written text, etc.). It is preferred because it allows films to be handled from a holistic perspective. In this context, the study attempts to analyse in depth both characters created by the directors using all the means of framing analysis.

\section{Sampling and Dimensions of Framing Analysis}

This study focuses on Lo Straniero and Yazgı films, which are the adaptations of a literary work, with framing analysis method. It will be useful to underline the dimensions of framing analysis in general outlines.

Frames determine how the event is passed to the viewer, how much the viewer needs to know, and which dimensions of the event should be seen. Framing analysis emphasizes that everything included in the frame is subjected to a selection and screening process, and those that are excluded as much as the ones selected are important. In summary, everything included in the frame reflects the view of the person who constructs the frame (Çakar Bikiç \& Akmeşe, 2019, p. 276). Framing analysis is used as a functional method for analyzing all media content. Framing analysis has three dimensions: Thematic framing is contextual framing and visual framing. Framing, composition, camera, and editing elements are included in the analysis within the visual framing (Akmeşe, 2017). These three dimensions of framing will be taken into consideration when performing comparative framing analysis of films. For the analysis, the subject of the film is involved in the thematic framing dimension, the story of the film is comprised in the contextual framing dimension, and the visual techniques that support the story are contained in the visual framing dimension. 
Framing is defined as selection and clarification, and to frame is defined as a particular problem definition for the item described, causal interpretation, moral evaluation, and selecting and clarifying certain aspects of perceived reality (Entman, 1993, p. 51). The essence of framing is based on choice and emphasis. The concept of framing analysis emerged as a result of Erving Goffman's work, and Goffman used this concept for the first time in his study Frame Analysis: An Essay on the Organization of Experience. Framing is an approach that states that reality is taken into a frame in the process of making individuals understand everyday life. It is based on the opinion that all media content (film, news, entertainment program, sports program, advertisement, column, etc.) is transferred to the audience with the perspective of the creator considering many parameters (Akmeşe, 2017).

\section{Albert Camus and The Stranger}

Albert Camus was born in Algeria in 1913, the son of a French father and a Spanish mother (Bronner, 2012, p. 167). Camus, regarded as the most important representative of existentialist literature, was deemed worthy of the Nobel Prize in Literature in 1957. Albert Camus's life began in Algeria in 1913 and ended in a car accident in 1960. The Stranger novel, originally called L'Étranger, is one of Camus's best known and worldrenowned works. Camus' characters in his novels have a number of common characteristics. They are content with the world of experience, do not seek meaning behind the visible, leave themselves easily to the coincidences they encounter, and remain indifferent to even the greatest pain they experience (Çağlıyan, 2014, p. 106). Albert Camus has three works in which he expresses his thoughts on the concept of Absurdism; The Stranger, The Myth of Sisyphus, and Caligula (Bronner, 2012, p. 43). In these works, it is emphasized that the individuals are aware that their actions will be repeated without results, and they become aware of the absurdity of their situation. Camus's The Stranger tells the story of Meursault, a stranger to his mother, his environment and society. The novel begins as follows: "My mother died today. Maybe yesterday, I don't know. I received a telegram from the nursing home: Your mother passed away. Tomorrow will be removed. Respects. I don't understand anything. Perhaps it was yesterday" (Camus, 2011, p. 15). The introductory paragraph, which begins with these sentences and reveals the unresponsiveness and insensitivity of the protagonist Meursault to the death of his mother, makes the readers feel that they are in the presence of an extraordinary character and subject. Camus framed the theme of The Stranger and the character of Meursault as follows: Meursault, the main character of the novel, 
is initially portrayed as someone who is not interested in anything except instant physical pleasures and honesty. Meursault does not care about money or promotion in his job and shows no emotional reaction when his mother dies. At his mother's funeral, he does not react except for the heat disturbance, but he pays attention to minor details such as the screws of the coffin and the clothes people wear. The day of the funeral is no different to him than the other days. The next day he goes swimming and meets a young girl and seduces her (Bronner, 2012, p. 44). Meursault is seen as an example of Camus' world view and the absurdity of life brought to life in the novel.

\section{Luchino Visconti and Lo Straniero (1967)}

Luchino Visconti, born in Milan on November 2, 1906, is considered to be one of the most important directors of the Italian new wave and world cinema. Growing up in a rich, conservative and aristocratic family, Visconti undergoes an educational process that focuses particularly on fine arts (Geitel, Prinzler, Schlappner, \& Schütte, 2006, p. 171). Luchino Visconti debuted as director in the history of Italian cinema with the film Ossessione (1942). One of the important features of this film is that it is shown as one of the first examples of the "New Realism" movement in Italian cinema. In 1942 Visconti completed his first film Ossessione. This film manifested itself as a work of art, and it was the birth of a new development that would be called New Realism in Italian cinema (Geitel et al., 2006, p. 7). New Realism describes a cultural movement that emerged in Italy as a reaction to the fascist era's attempt to cover up the truth, the literature and the art of escape. Although not as effective as in cinema, it also covers literature and other fields of art. The main features of the New Realism, which has influences from the Soviet Film-Eye (kino-glaz) theory, the French school of realism, British documentary cinema, and the Verisimo movement, are to convey social problems in natural spaces with a narrow budget, amateur actors and a simple narrative and make full use of the possibilities of black and white film (Sivas, 2010, pp. 42-43). A year before filming his first film, Ossessione, Luchino Visconti declared his understanding of cinema and art and the route he would follow in his article in the June 1941 issue of Cinema magazine Cadaveri, which was dangerous to write under the circumstances. In his defiant article, Visconti used the following statement: Will the day, which will give the fresh forces of our cinema the courage to say that the place of the dead is the cemetery, never come? (Geitel et al., 2006, p. 10). Visconti was quick to answer this question and throughout his film adventure, which began with his first film Ossessione, he made many important films in line with his understanding. 
Lo Straniero is a film directed by Visconti in the second half of the 1960s, when he bid farewell to New Realism and was regarded as a master-filmmaker. Lo Straniero is a 1967 film based on the world-famous novel L'Étranger (1942) by Albert Camus. In this film, Visconti remained committed to the novel as much as possible and tried to translate it into film language without interpreting it. It is possible to explain the subject of the film and Meursault's characteristics as follows: Meursault (Marcello Mastroianni) is a civil servant living in Algeria. He lives without any pursuit of purpose. He spends time watching life flowing down the street from the balcony of his single room in a ruined house. When he finds out about the death of his mother, who lives in a retirement home outside the city, he goes there immediately, seeks a vigil at the beginning of the dead and accompanies the coffin to the cemetery by passing through the heat-roasted fields. As soon as he returns to the city, he goes back to the swimming pool and runs into a girl he had met before (Anna Karina). He invites her to the cinema, then takes her home (Geitel et al., 2006, p. 130). As can be understood from this narrative, the script of the film follows the path of the novel The Stranger. It is not an easy task to process written texts and especially novel characters that require psychological description with cinematographic expression. However, Visconti seems to be successful in translating the novel into the language of cinema. The director included all the features of the novel protagonist within the frame of the film. The film continues in accordance with the narrative in the novel as follows: Meursault sits on a rock while walking with his friends on the beach, they encounter an Arab who they think is hostile to them, upon which the two Algerians and the French immediately turn back. After a while, Meursault walks back to where he meets the Arab with a pistol in his pocket. The glow of the sun gives the impression that the Arab has a knife. Meursault takes out his pistol and shoots in panic. He is arrested and sentenced to death. The greatest evidence against him during the trial was his "insensitive" attitude after the death of his mother and his unresponsiveness to the incident. Meursault expels the priest from his cell and feels integrated with the compassionate despair of the world (Geitel et al., 2006, pp. 130-131).

\section{Zeki Demirkubuz and Yazgı (Fate)}

Zeki Demirkubuz was born in Isparta in 1964 and is one of the new generation of Turkish filmmakers. In 1986, with the assistance of Zeki Ökten, he joined the field of cinema. Demirkubuz's directing adventure began in 1994 with CBlok (1994) (Pay, 2009, p. 125). Yazgı (2001) is Demirkubuz's free adaptation of Albert Camus'novel The Stranger, 
mostly through his filter, and to some extent loyal to the novel. As a matter of fact, Demirkubuz stated that he was inspired by the novel with these words: "I found the situation and the story in Albert Camus' novel The Stranger very close to me, and the story of the novel impressed me. As there was not a very detailed story in the novel, I combined it with another story I had" (Bal, 2004). The first film of Demirkubuz's Karanlık Üstüne Öyküler (Mental Minefields: The Dark Tales) trilogy, Yazgı (Fate), is about the story of Musa, a man who established a belonging to apathy (Pösteki, 2005, p. 88). Demirkubuz chose to use the name Yazgı (Fate) instead of The Stranger in his adaptation of the novel - and in several interviews, he stated that he valued the concept (fate) and named his daughter Yazgı because of it. Yazgı has various meanings such as God's approval, destiny, and eternal appreciation ("Yazgı," 2019). When we look at Demirkubuz's understanding of cinema and the films he directed, it is possible to see the reflections of the phenomenon of evil, pessimism and to a certain extent existentialism. In an article he wrote on Demirkubuz cinema, Ihsan Kabil expresses this situation as follows: Zeki Demirkubuz's cinematography, who is one of the new generation Turkish filmmakers, presents an intense pain, resentment, defeat, indifference, nihilism and arabesque-kitsch mixture (Pay, 2009, p. 5). Yazgı, as mentioned earlier, is Demirkubuz's free adaptation of Camus' novel The Stranger. The film draws attention as a work of inspiration rather than as a parallel to the main axis of the novel.

The subject of the film and the main character are framed by the director as follows; Customs accountant Musa (Serdar Orçin) imprisoned his existence in a sense of meaninglessness, nothingness, and absurdity with his unresponsiveness and inaction to the flow of life. His mother (who was living in the same house) dying; his colleague proposing marriage (and him saying yes even though he does not have any prior intention); and ultimately, being held in custody for the death of his boss's wife and two children; none of these lead to even a slight change in his state of mind. Because the only way to deal with situations in the face of the difference is by saying "it does not matter". In the center of the city, Musa is separated from everything, becomes lonely, silent, and acquires an audience. Atilla Dorsay described the character of the film as "someone who does not believe in anything, gives no value, unresponsive even to the death of his mother, and is even indifferent to his own death, an emotionless, unresponsive contemporary nihilist... a weird creature" (2013, p. 226). As can be understood from this narrative, the character Meursault in the novel came to life with the character Musa in Yazgı, but Musa is a more insensitive, pessimistic and to a certain extent pathological personality than Meursault. 


\section{FINDINGS}

In The Stranger, according to the plot and Meursault's view of life in the novel; immediately after the mother's death, Meursault goes to the beach, has fun, seduces the girl he meets and goes to the movies with her. Maria, the girl Meursault met, asks Meursault to marry her. Meursault accepts this request without hesitation because there is no difference for him whether to be married or not (Camus, 2011). In the novel, Meursault's character often uses the expression 'It's all the same' when making choices about life and emphasizes that life and preferences in life are meaningless. Meursault is kind but emotionally distant. Each choice is as meaningless as the next one, and a lot of coincidences take place one after the other (Bronner, 2012, p. 44). Absurd is an adjective that is used to characterize any kind of thought and judgment that pushes the limits of rationality or explicitly contradicts the laws of reason and common sense. In the context of philosophy, the expression "absurd", which expresses irrationality and meaninglessness in general, has been included in the philosophy literature by existentialists (Kierkegaard, Camus, etc.) and transformed into a completely different term. Absurd is used in existentialism to express the lack of meaning of human life and the world, the meaninglessness and aimlessness of the life we are left into (Güçlü, Uzun, Uzun, \& Yolsal, 2003, pp. 1236-1237). The plot in the novel develops with successive coincidences in accordance with Camus' absurd philosophy, and Meursault finds himself in prison at the end of an event that is not at all accountable. Meursault goes back to the beach with his fiancée, (...) friend Raymond Sintes and his girlfriend. Meursault doesn't react when his friend beats his girlfriend. They meet a group of Arabs, with a woman merchant and a bully among them, who have a bone to pick with Sintes. Mutual words are thrown, the men struggle, and then they are all dispersed. However, when Meursault comes back, dazzling in the sun and seeking some shade to escape the heat of the sun, he encounters one of the Arabs who draws a knife to him. Meursault shoots at him once, then four more times. The Arab lies dead on the ground. Police arrest Meursault. He is brought to court and sentenced to death (Bronner, 2012, p. 45). The Stranger has this narrative structure as the plot. In this aspect, it will be enlightening to explain the idea of absurdity which constitutes the intellectual source of the novel in terms of the depth of the subject and the full understanding of Camus's philosophical views conceptualized as absurd. At the heart of Albert Camus' thought lies the lack of meaning and nonsense of living. Both in his literary works and in his philosophical books, he describes the modern man trapped by the meaninglessness of life and trying to transform nonsense. In Camus, the concept of absurdity is related to the absence of 
God, one's mortality and the irrationality of the world (Tansel, 2007, p. 24). In the light of this information, when we look at the novel again, it becomes easier to understand Meursault's view of the world and the message trying to be conveyed in the novel. The developments in the novel, the balance of crime and punishment, and Meursault's attitudes towards their experiences follow a parallel course with Camus'"absurd" views. In the novel, the trial process holds an important place, as Meursault is tried and punished for reasons such as his attitudes, incompatibility with the aspects of society, and insensitivity to his mother's death, rather than for committing murder. Meursault is brought to court and sentenced to death, but this excessive punishment has little to do with the murder. Given the racist attitude of the French colonial administration in Algeria, it can be assumed that the punishment for such an offense is only a few years imprisonment. The main reason why the jury gives Meursault this punishment is Meursault's refusal to explain his actions during the interrogation and to lie about why he could not cry at his mother's funeral. This man, unfamiliar to himself and to society, begins to wait for death; in prison, he recalls his memories and forgets the boredom that dominated his past life. The priest comes and is turned away (Bronner, 2012, p. 45). As a result, Meursault, who lives aimlessly in a meaningless world and unfamiliar with society's value judgments, does not compromise with society and neither accepts asylum in religion nor lies to the jury. Camus's view of the world is a glimpse of the meaninglessness and absurdity of life. As a matter of fact, his sentiment in his work The Myth of Sisyphus is as follows: There is only one problem of philosophy that is really important, namely suicide. Making a judgment as to whether life is worth living is to respond to the fundamental problem of philosophy (Camus, 1983, p. 13). In this context, Camus' novel The Stranger can be considered as the trial of a contradictory individual by society over social norms, and this contradictory individual judging himself at the end of this societal trial.

In Lo Straniero, Visconti seems to have transferred the novel to the film in a way that coincides with the work. The film is an example of a one-to-one adaptation in that it reflects the details of the novel and almost every section occupying an important place in the novel. The process of the court in the novel, the dialogue between Meursault and the priest and the relations of Meursault with its neighbors are explained in similar frames in the film.

In Yazgı, Musa is framed as unresponsive, emotionless, withdrawn, and living as a character without faith (Pösteki, 2005, p. 88). Musa is so passive and indifferent that, 
although he witnesses his wife (Zeynep Tokuş) cheating on him, he does not react. When he gets accused of the murders he didn't commit, he doesn't care; it doesn't even make him happy to get out of death penalty; because, "it doesn't matter" for Musa. In the novel, Meursault's "It's all the same" approach, which he often uses, is "it doesn't matter" for Musa. Neither of the characters appreciate the importance of choices in life and it makes no difference to them. Yazgı (2001), if Demirkubuz's latest film Underground (2012) is left out, also attracts attention as the director's most intense work on Existentialist influences. Zeki Demirkubuz, who began his directing adventure with CBlok (1994), the first film he directed, always focused on defeated people, the phenomenon of evil, pessimism, and human suffering. It is possible to say that the director, who stated that say "Without Dostoyevsky, I would not make cinema" (Pay, 2009, p.101), is under the influence of Dostoyevsky and generally tries to shape the characters in his films with this effect.

\section{The Stranger: Dimensions of Framing and Structural Schema}

Albert Camus outlines the alienation of the individual to himself and society in the representation of the Meursault character in the novel The Stranger, through the absurd concept of existentialism. The main character of the novel is introduced just with his surname and no first name. Throughout the novel the character continues to exist as Mr. Meursault. Mr. Meursault's adventure begins with the news of his mother's death in a nursing home and ends with his relationship with his co-worker Marie, his accidental murder on the beach, his imprisonment, the trial process, and his execution.

The novel contextually focuses on the concept of absurdity, framing the life of Mr. Meursault, whose reading begins and ends with the execution of the telegram reporting the death of his mother. Mr. Meursault is the representation of absurdity in the Stranger. Mr. Meursault, does not show reactions such as pain and sadness that should be shown in the face of the death of parents, which is considered by society as one of the biggest sufferings in human life, and he resumes his routine life immediately after the funeral. He gets judged because of this unresponsiveness. The attitude 'It's all the same', which he uses in response to all the events in his life indicates that he is not in control of his life and that he is thrown into the world by external factors.

The words used in the novel are the equivalent of the image. It is possible to examine the choice of words and the description of events in the context of visual framing. The 
novel, written in simple language, from the perspective of Mr. Meursault, has opened the doors to the reader of the inner world of the character. The character is embodied by descriptions that will support thematic and contextual framing and is supported by the chaotic mood, restlessness, indifference, disbelief, narrow, stuck and isolated space depictions in the novel.

When the structural scheme of the novel, based in Algiers, is examined, besides the main character Mr Meursault, the other characters are his mother, Marie (his girlfriend), the elderly Salamano (the neighbor whose wife dies) and his dog, Raymond, Raymond's girlfriend, Emmanuel, his boss, killed Arabs, the judge, and a pastor. The main characters in the novel and the ancillary characters, even the plot, are representations of absurdity. The author describes the chaotic situation of the country in terms of characters and criticizes the community through these representations.

\section{Lo Straniero: Dimensions of Framing and Structural Schema}

When the film Lo Straniero is examined, it is seen that the thematic and contextual framing of the film largely corresponds to the novel. When the structural scheme of the film is examined, it is seen that Visconti's use of space in the film, the characters taking part in the plot, the temporal flow in the theme and the story coincide with the novel. Meursault, who has a very important place in the novel, has detailed relations with his neighbor, old Salamano and his dog in Lo Straniero. Meursault commits the murder as described in the novel and is executed at the end of the film.

When the visual framing dimension of the film is examined, the half-dark atmosphere of the spaces, the dark reflections of the characters (almost silhouettes), and close-up shots attract attention. The close-up shots in the scene where he goes to the nursing home for the burial of his mother supports Meursault's unresponsiveness and emotionless mood. In the film, the characters with low rhythm are shown against live nature and the passivity of individuals is sharpened with these images. Throughout the film, it is possible to state that the story, which is framed in terms of content and context, is supported by images with the camera angles used by the director, the choice of light, the music, and the fiction technique used. 


\section{Yazgı: Dimensions of Framing and Structural Schema}

When the film Yazgı is examined, it is seen that Zeki Demirkubuz has greatly benefited from the theme of The Stranger novel, but has reconfigured the story by combining it with his own stories in contextual and thematic contexts. Although The Stranger novel and the traces of existential philosophy are intensely felt and it is freely adapted, it is possible to say that the film treats The Stranger's existential philosophy in a superficial way by detaching it from its context (Pösteki, 2005, p. 88). Contextual framing based on the life of Musa, who is experiencing existential problems, puts the viewer in the eye of Musa's indifferent attitude towards his family, the people around him, and life. As Musa is physically living with his mother, his apathy actually reveals the existence of a deep abyss as stated in the detailed story of the film. One of the most important features that distinguish Yazgı from The Stranger and Lo Straniero is that Musa is not guilty and is released at the end of the film.

When the visual framing dimension is examined, it is seen that the camera angles and close-up shots that support the subject and contextual framing are used to emphasize Musa's insensitivity and unresponsiveness. In the film, music is almost nonexistent. The close-ups of Musa during dialogues were used in a way to support his spiritual void. The images used correspond to the thematic and contextual framework. The rhythm and technique of the film are in parallel with the rhythm of the thematic frame. When the structural scheme of the film is examined, it is seen that it differs from both the novel and Lo Straniero. Yazgı, unlike the other two works, differs in terms of temporal and structural schema. The plot, where the story takes place, and the life course of the main character are different.

\section{Comparison of Meursault and Musa}

In this section, in the axis of the absurd concept represented by the Meursault character created by Albert Camus' in The Stranger novel, it is examined how the Meursault and Musa characters created by two different directors were transferred to the big screen with similar and different frames. When Visconti transferred the film to the screen, he portrayed both the subject and the characters in a manner appropriate to the work, with the exception of small details. Meursault is framed as an unresponsive, emotionless character against what is happening around him, including the death of his mother. He doesn't believe in anything, except for that it is unnecessary to react in 
the face of events. He shows a silent reaction to the insincerity of social stereotypes. He thinks that nothing in life has a function other than instant happiness, and there is no difference between choices and alternatives. The phrase 'It's all the same', which he uses in the face of the choices throughout the film, reflects his point of view. He remains unresponsive even when sentenced to death for a crime he committed for a ridiculous reason. In general, upon the analysis of cinema style by Demirkubuz, it is observed that characters do not have specifically defined objectives and targets and they are framed as passive characters drifting from one set of circumstances to another and running after trivial objectives changing through film (Boz, \& Takımcı, 2015, p. 277).

While Zeki Demirkubuz borrowed his inspiration and basic characters from The Stranger, he established a new framework both in terms of theme and content. He starts by changing the name of the movie to Yazgı (Fate). It is possible to observe the profound effects of existentialism in the Yazgı film and especially the character of Musa. Because Musa finds it meaningless, he leaves the university in the fourth grade and continues his life as an accountant in a customs office. His relationship with others is framed as limited, dull, introverted, unbelieving, and unresponsive. He expresses his unresponsiveness to all events in his life through his line "it doesn't matter" throughout the film. For him, there is no difference between dying and living, getting married or staying single, being cheated on or not, or being guilty or innocent. When his colleague Sinem asks him "Can I ask you something?", he responds with "it doesn't matter, ask". In response Sinem says, "it doesn't matter, it doesn't matter, what matters to you?" and Musa responds 'Nothing matters'. In short, the death of his mother, marriage proposal, being married, testifying in court, his wife cheating on him, who the man is with whom she cheated on him, being falsely imprisoned, being put on trial, getting four years of imprisonment, killing someone, someone getting him in trouble, none of this matters to him, and his reaction to all this is "it doesn't matter". Framed as a character deprived of curiosity and questioning, Musa vanishes in nothingness and loses all his emotions and human reactions in the notion of nothingness. At this point, it is possible to say that the Musa of Zeki Demirkubuz is much more impervious than Visconti's Meursault, and is even at a pathological level. Throughout the film, there is no human reaction to be observed in Musa's mimics and gestures. A dull facial expression, callous gaze and calm, heavy behavior continue throughout the film. When he gets married, his mother dies, he sees his wife with another man in bed, he learns that his wife is cheating on him with his boss, he gets arrested, gets tried on death row, turned out to be innocent and gets released, there is no change in his emotions. He is like a carved out soul. 


\section{DISCUSSION AND CONCLUSION}

Human being and culture created by the human being occupy a central role in the production of all forms of works of art. Culture can be defined as the concept appertaining to humankind, referring to everything created by the human being and playing a crucial role in the analysis of the structure of societies. Culture has the attribute of being a byproduct of societies and also acting as their building block (Bahar, 2009, p. 53). In this study, three different works were analyzed. The creators of these works conveyed also their own cultural values to the fields of literature and cinema where they produced. Each discipline has its own specific rules. In this sense, it is not supposed to be neglected that each cultural component is defined differently in accordance with the values of the discipline that it resides in (Arda, 2016, p. 173). While creating their works, author and film directors reflected their corresponding cultural values through reference frameworks that they established.

At the end of the analysis of data obtained upon the analysis of the novel by Albert Camus, The Stranger, and the films adapted from this novel, Lo Straniero and YazgI, and the review of framing analysis and structural schemes of these works in light of above facts, it was ascertained that film directors applied different techniques in the process of adaptation of the novel to two films. It is perceived that Visconti fully adhered to the novel in the process of its adaptation to the film whereas Demirkubuz transferred only certain points of the theme to his film and set up a new framework with his own story.

When the Meursault and Musa characters are compared, Meursault in the movie is adapted as a parallel to the original Meursault in The Stranger novel in terms of the name, place, space and character traits as well as the development of the story. At this point, Visconti seems to have adapted the film and the character created by Camus without interfering with the universe. The character that Visconti brings to the screen is presented in a framing in which he sees himself as everyone else but does not express his emotions according to social norms and is marginalized by society. Zeki Demirkubuz has created a new story. Musa does not see himself as everyone else, but he stands out with his difference. Unlike the Meursault character, he is more active. He makes a conscious choice with his actions every time he is unresponsive, he doesn't leave himself to the flow of fate. It differs from Meursault at this point. While Demirkubuz frames the film's general story and character, he intensifies the traces of its intellectual structure. The director completely reshapes the character of Musa and, as in almost all his films, 
builds the character through contrasts. Musa is an atheist who does not wonder about anything, but also has no value and belief outside of God, and sees life as meaningless. He thinks people are hypocrites. For this reason, he doesn't care about people, nothing and no one matters to him. It is possible to say that the Musa of Zeki Demirkubuz is much more impervious than Visconti's Meursault and even at a pathological level. Throughout the film, there is no human reaction to Musa's mimics and gestures. A dull facial expression, callous eyes and calm, severe behavior draw attention. The fact that he does not react emotionally can be considered as an indicator of being a carrier of a spirit-free hollow body.

It is possible to answer the questions asked in the scope of the study as follows: While Demirkubuz made a free adaptation by using only the theme and certain characters, Visconti took the story directly; and Demirkubuz took only certain parts and created a new story. It is seen that the Yazgı film, in which the temporal and structural scheme of Lo Straniero film overlaps with the novel, exhibits a different structure. As a result, it is possible to state that Visconti and Demirkubuz created two different characters from the same work. Visconti has drawn a character frame that is equivalent to Meursault, with whom The Stranger's concept of unconcerned, profound and absurdity comes to life. Although Demirkubuz is nourished from the same source, he framed Musa as someone who finds everything pointless and meaningless at a pathological level, unresponsive, and different. In this context, as can be seen in the findings of the study, it is possible to express how much the director's point of view and framing are decisive in the process of making sense of a work.

In today's film industry, there is a tendency among film directors and producers to avoid literary sources with a certain style or author, as the results may undermine their careers, particularly those sources which are cherish by a strong fandom, an all-time classic, or pieces which contain complex, distinctive writing styles, almost impossible to translate to celluloid: the notion of unfilmability (Vergara, 2015, p. 156).

Film adaptation depends on different elements, namely, the source of adaptation's structure, the production conditions, the director's point of view and structure of sociocultural environment. Lo Straniero and Yazgı, which are the adaptations of a literary work, are evaluated according to the general context and main characters. The general context gives the general lines of the socio-cultural structure and the main characters provide the meanings of the director's point of view about life, individual and 


\section{unresponsive remaining for all the things. Also, further study beside this one could provide more detailed vision about the deep meanings of these films' structure and the directors' view of the life.}

\section{REFERENCES}

Akmeşe, Z. (2017). Framing on television and create the social point of view. (Doctoral Dissertation, Istanbul University, Istanbul, Turkey). Retrieved from https://tez.yok.gov.tr/UlusalTezMerkezi/

Arda, Ö. (2016, May). Ethnographic documentary in describing the culture. Paper Presented at the meeting of The 14th International Symposium Communication in the Millenium, İstanbul, Turkey.

Bal, A. (2004). Zeki Demirkubuz Röportajı. Retrieved from http://zekidemirkubuz.com/tr/basin/soylesiler/ roportaj_bapq_net.htm

Biricik, İ. (2016). Albert Camus'nün "Yabancı" romanında kimlik ve yabancılaşma problemi. Journal of Turkish Language and Literature, 2(3), 85-94. https://doi.org/10.20322/It.60590

Bolat, N. (2019). Geleneksel mecralarda çapraz medya ve transmedya anlatıları üzerine bir inceleme: Ağır Roman örneği. Selçuk Iletişim, 12(2), 503-531. Retrieved from https://dergipark.org.tr/tr/download/articlefile/769333

Boz, M. (2014). Sinemada uyarlama: Albert Camus'un Yabancı romanıla Zeki Demirkubuz'un Yazgı filminin karşılaştırılması. In N. Konukçu (Ed.), Sekans Sinema Yazıları Seçkisi 10 Sinema-Eleştiri-Kuram (pp. 113-135). Ankara, Turkey: Phoenix Yayınevi.

Boz, M., \& Takımcı, D. (2015). Zeki Demirkubuz filmlerinin ortak anlatı yapısı: Tema, zaman, mekân, karakter, sinematografi. Doğu Batı Dergisi, 72, 225-288. Ankara, Turkey: Doğu Batı Yayınları.

Bronner, E. S. (2012). Camus bir ahlakçının portresi (T. Sağlam, Trans.). İstanbul, Turkey: İletişim Yayınları.

Camus, A. (1983). Sisifos söyleni (T. Yücel, Trans.). İstanbul, Turkey: Adam Yayınları.

Camus, A. (2011). Yabancı (V. Günyol, Trans.). İstanbul, Turkey: Can Yayınları.

Çağlıyan, Ç. E. (2014). 21. Yüzyıl Amerikan ve Türk sinemasında saçma ve başkaldırı (Doctoral Dissertation, Ege University, İzmir, Turkey). Retrieved from https://tez.yok.gov.tr/UlusalTezMerkezi/

Çakar Bikiç, N., \& Akmeşe, Z. (2019) Zeki Demirkubuz'un arafta kalan kahramanları. In A. Oktan \& M. Aytaş (Eds.), Arafta imgeler: Sinemada kimlik, aidiyet ve ontolojik ikilemler (pp. 276-284). İstanbul, Turkey, Doruk Yayınları.

Çetin Erus, Z. (2005). Amerikan ve Türk sinemalarında uyarlamalar. İstanbul, Turkey: Es Yayınları.

Çetin Erus, Z. (2000). Romandan sinemaya uyarlamalar: Gerçekleştirilme süreci açısından bir değerlendirme. Maltepe Üniversitesi Illetişim Fakültesi Dergisi, 1, 45-55.

Çetin, Z. (1999). Bir anlatı formu olan romanın sinemaya uyarlanması (Doctoral Dissertation, Marmara University, Istanbul, Turkey). Retrieved from https://tez.yok.gov.tr/UlusalTezMerkezi/

Demirkubuz, Z. (2001). Yazgı [Film]. Turkey.

Dorsay, A. (2013). 100 yılın 100 Türk filmi. İstanbul, Turkey: Remzi Kitabevi. 
Entman, R. M. (1993). Framing: Toward clarification of a fractured paradigm. Journal of Communication 43(4), 5158. https://doi.org/10.1111/j.1460-2466.1993.tb01304.x

Geitel, K., Prinzler, H. H., Schlappner, M., \& Schütte, W. (2006). Luchino Visconti. İstanbul, Turkey: Es Yayınları.

Güçlü, A., Uzun, E., Uzun, S., \& Yolsal, Ü. H. (2003). Felsefe sözlüğ̈̈. Ankara, Turkey: Bilim ve Sanat Yayınları.

Kabadayı, L. (2013). Film Eleştirisi. İstanbul, Turkey: Ayrıntı Yayınları.

Kırel, S. (2004). Uyarlamak mı? Uyumlamak mı? "Tersyüz Adaptation". Galatasaray Üniversitesi Illetişim Dergisi, 1,

115-134. Retrieved from http://iletisimdergisi.gsu.edu.tr/tr/issue/7378/96591

Özön, N. (2000). Sinema, televizyon, video, bilgisayarlı sinema sözlüğü. İstanbul, Turkey: Kabalcı Yayınevi.

Pay, A. (2009). Yönetmen sineması Zeki Demirkubuz. İstanbul, Turkey: Küre Yayınları.

Pösteki, N. (2005). Türk sinemasına bakış: Yönetmen sineması. İstanbul, Turkey: Es Yayınları.

Scognamillo, G. (1973). Türk sinemasında yabancı uyarlamalar. 7. Sanat, 9, 62-73.

Sivas, A. (2010). Italyan sinemasına bakış. İstanbul, Turkey: Kırmızı Kedi Yayınevi.

Tansel, D. (2007). Varoluşçuluk ve yeni kara film: David Lynch örneği (Master Dissertation, Ankara University, Ankara, Turkey).

Tarkovsky, A. (2018). Tarkovski'nin edebiyat ve sinema kıyaslaması. Retrieved from http://www.edebiyathaber. net/tarkovskinin-edebiyat-ve-sinema-kiyaslamasi/

The Stranger (Camus novel). (n. d.). Retrieved July 19, 2019 from https://en.wikipedia.org/wiki/The_Stranger_ (Camus_novel)

Uyarlama (n. d.). Retrieved July 25, 2019 from https://sozluk.gov.tr/

Vergara, Alejandro. (2015). Literary Film Adaptation for Screen Production: the Analysis of Style Adaptation in the Film Naked Lunch from a Quantitative and Descriptive Perspective. Logos: Revista de Lingüística, Filosofía y Literatura. 25. 154-164.

Visconti, L. (1967). Lo Straniero [Film]. Italy.

Yazgı. (n. d.). Retrieved July 23, 2019 from https://sozluk.gov.tr/ 
